\title{
Management of Complex Risk of the Airline's Activities in order to Ensure Economic Security
}

\author{
Anna A. Burdina, Nataliya V. Moskvicheva, Narmina O. Melik-Aslanova \\ Moscow Aviation Institute (National Research University), Volokolamskoe Highway, 4, \\ 125993, Moscow, Russia
}

\begin{abstract}
The study proposes to consider the concept of complex risk of an airline from the position of a systematic approach and define risk as a threat to the economic security of an airline. The analysis of theoretical and methodological aspects of risk assessment is carried out. One method is proposed for determining and predicting a complex risk as a threat to the economic security of an airline based on an analysis of the probability of events and the impact on the company's activities in order to make effective management decisions to strengthen the economic security of an airline.
\end{abstract}

Keywords - economic security; system; threats; risk; forecasting; flight safety risk; corruption risk; professional risk; probability; impact; efficiency; risk assessment methodology.

\section{Introduction}

The analysis shows that the complexity that absolutely all companies have during their activities is a large variety of risks. The research hypothesis is to approach risk as a system.

DOI: $10.18421 /$ TEM104-06

https://doi.org/10.18421/TEM104-06

Corresponding author: Nataliya V. Moskvicheva, Moscow Aviation Institute (National Research University), Moscow, Russia.

Email: moskvicheva_mai@mail.ru

Received: 21 April 2021.

Revised: 02 September 2021.

Accepted: 09 September 2021.

Published: 26 November 2021.

(c) BY-NC-ND (C) 2021 Anna A. Burdina, Nataliya V. Moskvicheva \& Narmina O. Melik-Aslanova; published by UIKTEN. This work is licensed under the Creative Commons Attribution-NonCommercial-NoDerivs 4.0 License.

The article is published with Open Access at www.temjournal.com
That is, risk as a system (complex risk) is a set of elements (risk components) connected by relations that affect the purpose of the company's activities and its financial result. The objectives of the research are the following: to study theoretical aspects of risk management; to analyze risk management mechanisms of PJSC Aeroflot - Russian Airlines (Aeroflot); to develop risk assessment procedure and mechanism for calculating complex risk at Aeroflot.

Approaches to risk management from the point of view of making decisions to identify possible losses can be presented in the following classification: active, adaptive and conservative approaches [1], [2]. Active risk management is based on the use of the maximum possible risk management tools to mitigate them. This approach means that all business operations are carried out after taking measures to prevent factors and events that carry a risk for the main activity of the enterprise.

Adaptive approach is based on the adaptation of the enterprise to the current situation, taking into account the required level of economic security. This approach means managing risks directly in the course of the current situation. In this case, it is impossible to completely prevent the risks, but only one part of the potential losses can be avoided.

Conservative (passive) approach is based on management and mitigation of the impact of damage that has already occurred. In this case, the main goal of management is to contain the consequences of the losses that have occurred within the framework of one unit or one financial transaction. Despite the fact that with this method, the costs of managing financial risks are significantly lower compared to the previous ones, the potential damage resulting from the occurrence of a risk event can be much higher. Therefore, this approach is rarely used in enterprises.

Aeroflot has one of the youngest fleets in the world. As of April 1st, 2020, it operates 247 aircrafts, the average age of them is 5 years. The number of aircraft by type is presented in the Table 1 . 
Table 1. Aeroflot aircraft fleet, units

\begin{tabular}{|l|c|c|c|c|c|c|c|}
\hline Airplane model & B777 & B737 & A350 & A330 & A321 & A320 & SSJ-100 \\
\hline Number of aircraft & 19 & 47 & 1 & 19 & 33 & 74 & 54 \\
\hline
\end{tabular}

The main tasks are to significantly increase the international transit passenger traffic, to open regional bases throughout Russia, to increase regional traffic and to multiply the number of the latest Russian aviation equipment in the aircraft fleet.

Aeroflot group includes:

1. Three aviation subsidiaries:

- Pobeda Airlines LCC;

- Rossiya Airlines;

- Aurora.

2. Five non-aviation companies:

- JSC Sherotel;

- JSC AeroMar;

- Aeroflot Aviation School;

- Aeroflot-Finance LLC;

- A-Technics LLC.

The organizational structure within Aeroflot is a functional structure with division of functions between structural divisions with subordination of all subordinate departments to them. The structure provides for the subordination of the subdivision / employees to higher managers in the area of their activity. Russian market for passenger air transportation is highly consolidated: at the end of 2019, three largest players accounted for more than $50 \%$ of the total passenger traffic; compared to the previous year, the structure of the Russian market has remained virtually unchanged. These three airlines in Russia in terms of the number of passengers include Aeroflot, S7 Airlines and Ural Airlines [3], [4].

\section{Literature Review}

The works of many Russian and foreign researchers are devoted to approaches to assessing the risks of enterprise activities [5], [6]. Risk analysis methods are presented in international standards and GOST (set of technical standards). However, in the literature, the issues of assessing the integrated risk of an airline as a threat to economic security, taking into account force majeure circumstances (pandemic 2019-2021), have not been sufficiently worked out. Criteria for assessing the probability and impact of risk events on the activities of carriers have not been identified [7].

\section{Materials and Methods}

According to G. Uvarova "Risk as an event is a deviation from the goal or failure to achieve the goal" [8]. In the activities of the country's largest airline, the risk may manifest itself in lower volumes of passenger traffic, revenue, sharp fluctuations in currency and world prices for aviation fuel, credit (leasing) and investment risks. The scale of such risks can be different: from the loss of part of the income to the complete loss of the invested funds. An idea of the causes of risks in the activities of the airline can be given by referring to the company's policy, in accordance with which it is possible to distinguish the following [9]:

Business risks: risks of losses, within which the objects of solutions are the demand, cost and price of the services provided:

- risk of reduced passenger traffic;

- reputational risks;

- service quality risk;

- environmental risks.

Operational risks: risks of losses as a result of inadequate or erroneous internal processes, actions of employees and systems or external events [10]:

- flight safety risks;

- aviation security risks;

- risks of safe work;

- information security risks.

Financial risks: risks of losses associated with financial activities [11]:

- market risks;

- liquidity risk;

- credit risk.

Compliance risks: risks of losses when applying legal sanctions and sanctions of regulatory bodies, these include the risks of compliance with external legal norms.

The mechanism for implementing the risk management process at Aeroflot is based on the scheme shown in the Figure 1.

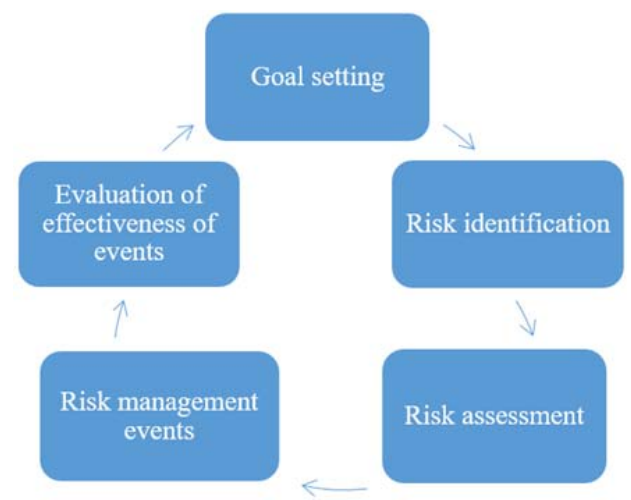

Figure 1. Risk management process at Aeroflot 
The setting and formulation of business process goals has to meet the criteria of SMART system (Specific, Measurable, Achievable, Relevant, Time bound) and the acceptable risk or risk limit.

Criteria for SMART goal setting system are the following [12]:

- S - Specific;

- M - Measurable;

- A - Achievable;

- R - Relevant;

- T - Time bound.

Acceptable risk (preferred risk) is the measure of risk that the company is ready to accept (considers it justified and acceptable) when performing functions within its competence in the implementation of financial and economic activities.

Acceptable risk ensures that the company's strategy is aligned with its operational and financial capabilities.

The concept of acceptable risk implies a system of concepts presented in the Figure 2. [11].

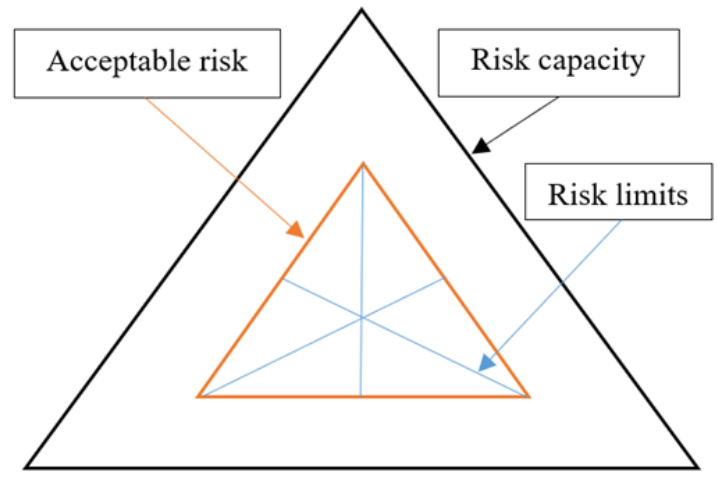

Figure 2. Acceptable risk concept

Risk limit is the share of acceptable risk allocated for a specific financial and economic activity, portfolio of risks or company entity.

Risk identification is the process of identifying and describing elements of risk. For each risk, a causal relation is established: risk factor - reason of risk risk - consequences.

Key characteristics to which the risk should correspond are the following [1]:

- Probabilistic nature: the risk may or may not materialize in the course of the company's financial and economic activities;

- Adverse consequences: the risk is always characterized and measured by the level of possible adverse consequences;

- Subjectivity: the risk depends on the quality and quantity of information about it, staff qualifications, etc.;

- Significance: the consequence of the risk should directly affect the interests of the company.

The risk factor is a factor that affects the final financial and economic performance of a company [1].
When identifying risks, the impact of the following risk factors is considered: human factor, IT factor, technical factor, technological factor and external factor. Risk identification is carried out as a part of the initial identification of risks and in the framework of current activities. Initial identification of risks is carried out by compiling a register of risks based on an analysis of goals, objectives, business processes, internal regulations, reporting and previous data on realized risks. Identification of risks in the framework of current activities is carried out by making changes to existing register [13].

Risk assessment is carried out through the use of parameters: probability of implementation and impact of consequences. Risk assessment is a number that is the result of multiplying the values of the estimates of the probability of risk realization and the impact of the consequences of risk realization.

Risk assessment is used to rank risks when making decisions in current activities and developing measures to minimize them. Risk management measures are subdivided into preventive and in the event of a risk realization. The main methods of risk management in the company are: avoidance, transfer, reduction (probability and impact) and risk acceptance.

The choice of the optimal risk management measure is carried out according to the following criteria:

- efficiency;

- economic expediency;

- compliance;

- feasibility;

- reliability;

- consideration of adverse consequences.

This is followed by an assessment of effectiveness, which includes [14]:

- assessment of functional efficiency carried out on the basis of information on realized risks, risk factors, on changes in risk parameter assessments in the risk register and on adherence to acceptable risk;

- assessment of procedural efficiency carried out on the basis of information on compliance or violation of the requirements of internal regulatory documents in terms of risk management.

For a comprehensive risk analysis of Aeroflot, it is recommended to apply risk assessment methodology based on the use of two parameters: probability of occurrence and impact of the consequences of risk realization (losses, severity of consequences).

Risk $=$ probability $*$ impact

In the forecast case, the probability is assessed on a five-point scale with the assignment of an appropriate assessment (Table 2.). 
Table 2. Scale for assessing probability and impact

\begin{tabular}{|c|c|c|c|c|c|}
\hline Probability & more than $80 \%$ & $(60 \%-80 \%]$ & $(30 \%-60 \%]$ & $(5 \%-30 \%]$ & less than $5 \%$ \\
\hline Impact & Extremely high & High & Average & Low & Extremely low \\
\hline Assessing probability and impact & 5 points & 4 points & 3 points & 2 points & 1 point \\
\hline
\end{tabular}

This information is more clearly presented by the risk probability and frequency matrix in the Table 3.

Table 3. Matrix for assessing probability / frequency of risk origin

\begin{tabular}{|c|c|c|c|c|c|c|c|}
\hline \multicolumn{2}{|c|}{ Probability score } & \multirow[b]{3}{*}{ High quality } & \multirow[b]{3}{*}{ Probability } & \multirow{2}{*}{\multicolumn{4}{|c|}{$\begin{array}{c}\text { Frequency } \\
\text { Frequency of process }\end{array}$}} \\
\hline \multirow[b]{2}{*}{ Impact } & \multirow[b]{2}{*}{ Evaluation } & & & & & & \\
\hline & & & & $\begin{array}{c}\text { at least once a } \\
\text { day }\end{array}$ & $\begin{array}{c}\text { at least once } \\
\text { a week }\end{array}$ & $\begin{array}{l}\text { at least } \\
\text { once a } \\
\text { month }\end{array}$ & $\begin{array}{c}\text { at least once } \\
\text { a quarter }\end{array}$ \\
\hline $\begin{array}{l}\text { Extremely } \\
\text { high }\end{array}$ & 5 & $\begin{array}{l}\text { Will almost certainly } \\
\text { happen }\end{array}$ & $\begin{array}{l}\text { more than } \\
80 \%\end{array}$ & $\begin{array}{l}>270 \text { events } \\
\text { per year }\end{array}$ & $\begin{array}{c}>38 \text { events } \\
\text { per year }\end{array}$ & $\begin{array}{c}>9 \text { events } \\
\text { per year }\end{array}$ & $\begin{array}{l}>3 \text { events } \\
\text { per year }\end{array}$ \\
\hline High & 4 & $\begin{array}{l}\text { The event is likely enough. } \\
\text { More likely to happen than } \\
\text { not }\end{array}$ & $60 \%-80 \%$ & $\begin{array}{c}180-270 \\
\text { events per year }\end{array}$ & $\begin{array}{c}26-38 \text { events } \\
\text { per year }\end{array}$ & $\begin{array}{c}6-9 \text { events } \\
\text { per year }\end{array}$ & $\begin{array}{c}2 \text { events per } \\
\text { year }\end{array}$ \\
\hline Average & 3 & $\begin{array}{l}\text { Chances of the event are } \\
50 / 50\end{array}$ & $30 \%-59 \%$ & \begin{tabular}{|c|}
$\begin{array}{c}90-179 \text { events } \\
\text { per year }\end{array}$ \\
\end{tabular} & $\begin{array}{c}13-25 \text { events } \\
\text { per year }\end{array}$ & $\begin{array}{c}3-5 \text { events } \\
\text { per year }\end{array}$ & $\begin{array}{c}1 \text { event per } \\
\text { year }\end{array}$ \\
\hline Low & 2 & $\begin{array}{l}\text { The event is unlikely. } \\
\text { Rather not happen than } \\
\text { happen }\end{array}$ & $5 \%-29 \%$ & $\begin{array}{c}\text { 20-89 events } \\
\text { per year }\end{array}$ & $\begin{array}{c}\text { 3-12 events } \\
\text { per year }\end{array}$ & $\begin{array}{c}1-2 \text { events } \\
\text { per year }\end{array}$ & $\begin{array}{l}\text { could happen } \\
\text { in the } \\
\text { coming years }\end{array}$ \\
\hline $\begin{array}{l}\text { Extremely } \\
\text { low }\end{array}$ & 1 & $\begin{array}{l}\text { It is highly unlikely. The } \\
\text { possibility of the occurrence } \\
\text { of the event is almost ruled } \\
\text { out }\end{array}$ & less than $5 \%$ & $\mid \begin{array}{c}<20 \text { events per } \\
\text { year }\end{array}$ & $\begin{array}{l}<3 \text { events } \\
\text { per year }\end{array}$ & $\begin{array}{l}\text { will not } \\
\text { happen } \\
\text { for years }\end{array}$ & $\begin{array}{l}\text { will not } \\
\text { happen for } \\
\text { years }\end{array}$ \\
\hline
\end{tabular}

Final risk assessment is made by multiplying the scores obtained in assessing the impact of risk and its probability. Depending on the value obtained, we can determine which risk zone it belongs to. In the study, the division into risk zones (red, yellow, green) was carried out in order to form a risk map. The red zone is the highest risk zone, the yellow zone is moderate and the green zone is the lowest risk.

The impact scores for each risk were scored based on the severity of the consequences the airline suffered after each risk was met. The results are presented in the Table 4.

Table 4. Risk assessment of Aeroflot in 2019

\begin{tabular}{|l|c|c|c|}
\hline \multicolumn{1}{|c|}{ Risks } & Impact & Probability & Evaluation \\
\hline Flight safety risks & 4 & 5 & 20 \\
\hline Reputation risks & 3 & 5 & 15 \\
\hline Corruption risks & 1 & 1 & 1 \\
\hline Professional risks & 4 & 5 & 20 \\
\hline Environmental risks & 1 & 1 & 1 \\
\hline Compliance risks & 1 & 5 & 5 \\
\hline Operational risks & 4 & 5 & 20 \\
\hline Liquidity risk & 4 & 5 & 22 \\
\hline Financial performance risk & 3 & 5 & 13 \\
\hline
\end{tabular}

The assignment of the corresponding points is conditioned by the analyzed events. The flight safety risk is estimated at 20 points, which indicates that this risk falls into the "red" zone. Reputational risks received 15 points, respectively, they are also in the "red" zone. Corruption risks in the reporting year received an assessment of 1 point, since there were no cases of deviation from the acceptable risk under this section. Professional risks in 2019 were estimated at 20 points due to the events that occurred in the plane crash in the second quarter.
Environmental risks are assessed at 1 point, so it automatically falls into the category of risks with extremely low impact, that is, in the "green" zone.

The risk assessment of compliance with external standards is 5 points and it is included in the "yellow" zone of risks of medium impact.

Operational risks in 2019 are estimated at 20 points, since they include a combination of flight safety risks, professional risks and information security risks. 
After evaluating each indicator separately in accordance with the norms, we will arrange the specific weight of each of them. Then it is necessary to add the products of the assessment and the weight of each coefficient to obtain the final assessment for the category of liquidity and the category of financial stability. After that, in a similar way, calculations were made for the total risk of liquidity and stability.

\section{Results}

Based on the assessments of all the above analyzed risks, we will draw up a diagram of the risks under consideration, presented in the Figure 3. All calculated risks are placed in a circle, and the internal scales show the risk assessment in accordance with the number of points assigned to it.

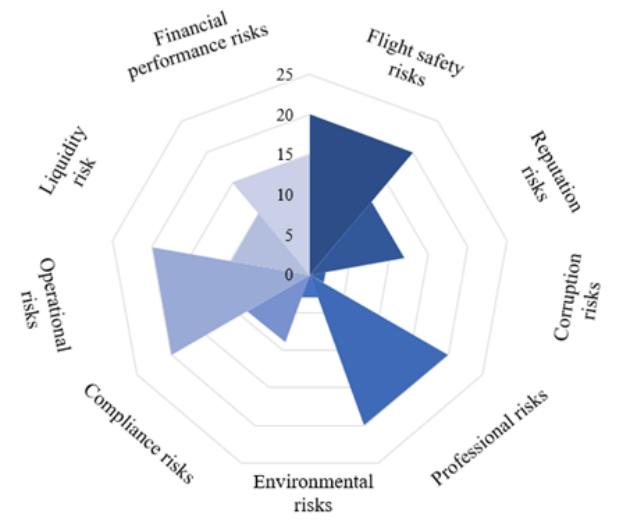

Figure 3. Acceptable risk concept

To conduct a comprehensive analysis of these risks, we place the weights for each risk in accordance with their importance for the airline's activities (Table 5.).

The distribution of weights is due to the degree of importance for the airline of a specific risk, depending on the current situation for the past reporting period. The maximum share is assigned to the risk that the airline should pay most attention to, based on the assessment of the impact of the corresponding risk in 2018. This arrangement is necessary to stabilize the risk situation in the reporting period.

Table 5. Risk assessment of Aeroflot in 2019

\begin{tabular}{|l|c|c|}
\hline \multicolumn{1}{|c|}{ Risks } & Points & Weight \\
\hline Flight safety risks & 20 & 0.2 \\
\hline Reputation risks & 15 & 0.15 \\
\hline Corruption risks & 1 & 0.02 \\
\hline Professional risks & 20 & 0.1 \\
\hline Environmental risks & 1 & 0.03 \\
\hline Compliance risks & 5 & 0.05 \\
\hline Operational risks & 20 & 0.25 \\
\hline Liquidity risk & 22 & 0.1 \\
\hline Financial performance risk & 13 & 0.1 \\
\hline
\end{tabular}

Expert weighting is explained by the following factors.

The highest priority for the airline is its operating activity, which is the main direction that brings it the bulk of its revenue.

In second place in terms of importance is aviation security, which is a part of the operational activities and takes up the bulk of it.

Further, there are reputational risks with a weight of 0.15 . The corresponding weight was set due to the direct dependence of the company's reputation and its existence in the market, and, accordingly, operating activities. In the event of the maximum consequences of reputational risks, the main activity of the company is terminated due to the absence / minimization of passenger traffic, and, accordingly, revenue.

Financial risks: liquidity and efficiency risks of the airline. It is advisable to introduce a parameter for accounting for force majeure circumstances (for example, COVID-19). In addition, any company of an international level interacts with the turnover of currency in the world, therefore Aeroflot depends on fluctuations in exchange rates, which implies a rather large risk of financial losses from exchange rate differences in the cost of fuel.

Compliance risks with external regulations, environment and corruption risks have the lowest weights, since the company exercises maximum control over compliance with legislation and environmental standards: in Russia and abroad.

After assessing the airline's risks in 2019 and assigning them the appropriate weights, using formula (1), it is recommended to calculate the complex risk for Aeroflot, which represents the totality of all company risks.

$$
\text { Risk }_{\text {complex }}=\frac{\text { impact }_{\mathrm{i}} \times \text { probability }_{\mathrm{i}} \times \text { weight }_{\mathrm{i}}}{\sum \text { weight }_{\mathrm{i}}},
$$

Thus, we obtain an estimate of the complex risk, which is equal to 17.02 points. Consequently, all risks in the airline's activities in 2019 can be assessed at 17.02 points, which means that the complex risk automatically falls into the category of risks that have a high impact and are in the "red" zone.

In conclusion, we can say that Aeroflot in 2019 has undergone many events that could not be predicted to minimize their consequences. Accordingly, the results of these adverse consequences negatively affected the performance and increased the value of the complex risk. The main adverse event of 2019 was the plane crash at Sheremetyevo, the consequences of which affected almost all categories of the airline's risks. In general, the categories of safety, professional and reputational risks were heavily impacted. This technique is recommended to be used for predicting complex risk and developing solutions to minimize them. 


\section{Discussion}

The study recommends a methodology for assessing and predicting complex risk as a factor of threats to the economic security of a company. The analysis is based on determining the probability of a risk event and the impact on the company's activities. The most influential are financial, operational and flight safety risks, since all of the airline's activities are based on them. However, only one of the risks is in the "red" zone, this is the risk of financial efficiency, since it is quite difficult to predict force majeure circumstances (for example, COVID-19), possible changes in the external aviation fuel market. Also, fluctuations in exchange rates are subject to a rather complicated forecast, and the airline is not able to impact it. It is advisable to form a risk map.

\section{Conclusion}

The authors offer an original interpretation of the complex risk of the airline's activities from the position of a systematic approach. It is advisable to define risk as a threat to the economic security of the airline. The study analyzes theoretical and methodological aspects of risk assessment. Risk assessment methods are analyzed. A classification of the components of the airline's complex risk has been developed: flight safety, reputational, professional, environmental, financial, corruption risks, etc. The quantitative and qualitative parameters of the risk components are determined: probability and impact one. It is recommended that the financial risk assessment be carried out taking into account possible force majeure circumstances (for example, COVID-19). One method has been developed for determining and predicting a complex risk as a threat to the economic security of an airline based on an analysis of the probability of events and the impact on the company's activities in order to make effective management decisions to strengthen the economic security of an airline. The practical implementation of the technique has been carried out. There is the risk forecast for 2020 .

\section{References}

[1]. Badalova, A. G., \& AV, P. (2015). Upravleniye riskami deyatel'nosti predpriyatiya. M.: Vuzovskaya kniga, 236. (in Russian).

[2].Dubinsky, M. O., \& Burdina, A. A. (2021). Voprosy klassifikatsii riskov ekonomicheskoy bezopasnosti predpriyatiya. RISK: Resursy, Informatsiya, Snabzheniye, Konkurentsiya, 1, 59-62. (in Russian)

[3].Crouhy, M., Galai, D., \& Mark, R. (2006). The essentials of risk management (Vol. 1). New York: McGraw-Hill.

[4].Kanashchenkov, A. I., Novikov, S. V., \& Iniesta, D. V. (2019, May). Technology formation of the mission of micro-level management enterprise in aviation. In IOP Conference Series: Materials Science and Engineering (Vol. 537, No. 4, p. 042040). IOP Publishing.

[5].Komarova, N. V., Zamkovoi, A. A., \& Novikov, S. V. (2019). The fourth industrial revolution and staff development strategy in manufacturing. Russian Engineering Research, 39(4), 330-333.

[6].Wong, S., \& Brooks, N. (2015). Evolving risk-based security: A review of current issues and emerging trends impacting security screening in the aviation industry. Journal of Air Transport Management, 48, 60-64.

[7].Addepalli, S., Pagalday, G., Salonitis, K., \& Roy, R. (2018). Socio-economic and demographic factors that contribute to the growth of the civil aviation industry. Procedia Manufacturing, 19, 2-9.

[8].Glasova, E. S., \& Uvarova, D. A. (2018). Riski proyektnogo finansirovaniya i metody upravleniya imi. Biznes-obrazovaniye v ekonomike znaniy, 3(11), 3, 1517. (in Russian).

[9].Insua, D. R., Alfaro, C., Gómez, J., HernandezCoronado, P., \& Bernal, F. (2018). A framework for risk management decisions in aviation safety at state level. Reliability Engineering \& System Safety, 179, 74-82.

[10]. Gillen, D., \& Morrison, W. G. (2015). Aviation security: Costing, pricing, finance and performance. Journal of Air Transport Management, 48, 1-12.

[11]. Davydova, E. Yu. (2016). Finansovyye riski: metody otsenki i podkhody k upravleniyu. Territoriya nauki, 3, 70-75. (in Russian).

[12]. Weintraub, J., Cassell, D., \& DePatie, T. P. (2021). Nudging flow through 'SMART'goal setting to decrease stress, increase engagement, and increase performance at work. Journal of Occupational and Organizational Psychology, 94(2), 230-258.

[13]. Chaika, N. K. (2021). Formation of Development Strategy for Industrial Enterprise. Quality-Access to Success, 22(180), 20-26.

[14]. Eremin, M. Y., Moskvicheva, N. V., \& MelikAslanova, N. O. (2020). Servicing of imported airplanes by means of performance-based logistics. Russian engineering research, 40(2), 146148. 